\title{
Strategic Cultural Footprint of Colonial Diplomacy: Singaporean Interaction with the Neighbourhood of Maritime Society of Belakang Padang (Batam, Indonesia)
}

\author{
M Halkis \\ Faculty of Defence Strategic, Universitas Pertahanan Indonesia, Bogor, Indonesia 16810 \\ \{halkis@idu.ac.id\}
}

\begin{abstract}
The sustainable development plan is required to integrally include all stakeholders in a neighborhood. The aim of this research is to analyze neighborhood relationships between two largely different cultures between the city-states of Singapore and maritime society of Belakang Padang that left behind by modernization. It departs from an assumption that the development of strategic culture results in the advancement on one side but left imbalance development on the other side. Utilizing the approach method of symbolic interaction, it reveals different usage of ethics and emic values in symbols and significations. Strategic cultural footprint as the heritage of colonial diplomacy is still visible on society's genealogy, value development, and policy difference between the governments. The obedience of symbols usage and perception difference between the societies have created exclusivity and the inter-society gap so that strategic culture becomes separating lines between the societies. Efforts to integrate those two geographically neighboring societies can be done by involving various stakeholders through strategic management framework to develop its potentials and resources.
\end{abstract}

Keywords: Strategic Culture, Strategic Management, Colonial Diplomacy, CityState, Maritime Cooperation

\section{Introduction}

Even though Singapore is the third richest country in the world, according to the IMF in 2018, but it does not have significant effect towards the development of its local societies in the neighboring region, especially the closest maritime society of Belakang Padang district (Batam, Indonesia) despite its only separated by 5.6 kilometers between Takong Island (Singapore) and Nipah Island of Belakang Padang. If Singapore intends to be involved in developing the maritime potentials in Belakang Padang, there are a lot of cooperation activities with associated stakeholders of Belakang Padang. It is necessary to be interrogated about the society relationship pattern between Singaporean and maritime people of Belakang Padang. If Singapore develops based on strategic management, then the relationship between Singapore and its neighboring people will result in mutualistic integration. But if Singapore develops based on strategic culture, then the relationship becomes a rivalry or even no established relationship at all. 
Basiago[1] argues that balancing the development between a society and its neighborhood by framing the environmental-friendly development plan can protect the natural system of city development and it involves the surrounding societies in its process. Its logic is limited with the richer state should profit their neighbors. If using the management of environmental resources using strategic management, it should be integrated with various stakeholders to manage the resources, but if it is put in the context of strategy culture, then each culture have their way and perceptions towards the resources, it can be the closest friend is the first opponent that need to get rid of so that one group and the others are started by suspiciousness and avoiding each other. This way was used by the old colonial power on its colony land.

Booth [2] considers that strategic culture helps shaping behavior on issues such as the utilization of force in international politics, sensitivity towards external danger, civilianmilitary relationship, and strategic doctrine, for that the problem of strategic culture in the framework of war and peace matters. Its relevance in this globalization era is needed to be reviewed. Old heritages that have colored society's culture may curb its society or change in accordance with the developing change and environmental needs. Perception of Singaporeans towards its surroundings needs to be examined on its implications towards local society.

Davis [3] thought that Singapore perceives Indonesia as a terrorist's haven. This judgment has a reason that Malacca strait region, by history, is controlled by pirates, and most of them are Indonesian. During the Aceh Independence Movement (1976-1998), it was used to search for logistical support. And then when Indonesia become independent in 1945, compared with the separation of Singapore from Malaysia in 1965, Indonesia during developing interaction to the neighboring countries has its own dynamics. Indonesia was independent in a heroic way because they have to battle against the colonial forces. It is different from Singaporeans that inherited by the British colonials and then separating constitutionally from Malaysia. The capture of Usman and Harun, Indonesian elite forces in 1968 in Singapore also coloring relations between the two countries. Even though that judgment does not profit Indonesia, but it a reality that has to be accepted. Therefore, the connecting of two strategic culture is hard to implement due to the cultural system and perceptions between one and another cannot be met.

Soulard[4] states that stakeholders explore the dimension of trust, reciprocal, and cooperation in the context of bonding and bridging social modal. This research's result shows the support of the stakeholders for the plan and strategic goals will be increased as the bonding and bridging the intensity of social modal. Recommendations will be given for the strategic planning process by applying strategic plan. Further research that departs from this is recommended to use the application of social modal theory.

\section{Method}

The research method that is used in this research is the qualitative method, using the approach of interaction between the societies that differ in the usage of cultural symbol. The symbol differences between the two groups or more clarify the difference of concept and values in a group. The focus of this method of research is on the researcher's understanding about the social meaning and life in certain context [5]. Departs from the research's aim to gather explanations about the inability of Belakang Padang society (Batam, Indonesia) in harnessing Singapore's potentials as a developed industrial country that geographically closes. Research's assumption believes that the distance between Singapore and its neighboring country as colonial production in building exclusivity of strategic culture by putting forward the identity, norm, and thinking paradigm differentiator. Behavior and culture of the surrounding society is the reflection of the product of colonial inheritance. Strategic culture is 
developed in the contestation of fighting over the environmental resource and protecting the area from the potential enemy. It is to understand deeper the impacts of post-colonial strategic culture in the context of more advanced development for the marginalized society in the future. Research data is gathered through interviews, observation, and literature from various sources. Data then analyzed by classifying it in a rational construction so it can result in conclusion to understand the phenomenon of the relationship of Singaporean society as the people of a developed country towards its neighborhood's society.

\section{Results and discussion}

\subsection{Research Results}

\subsubsection{Genealogy of Strategic Culture of the city-state of Singapore vs. Maritime Society of Belakang Padang, Batam}

Andaya [6] explains that based on Arabic document of the 9th century, the Malay language became society's adhesive aspect of Malacca strait region. Pantun became the identity of intersociety communication method. This explanation also supported by a historian, Godinho de Eredia that explains the mentioned Malacca strait as Malayan Sea. So that Malacca Strait and Singapore Strait is a unity during the trading history, Malay colonization until they receive political and economic supremacy.

Trocki[7] stated that Singaporean history is not enough to be viewed as the part because the Old Johor history illustrates historical, geographical, and dynasty relationship between the nations, includes Pahang, Terengganu, Selangor, Perak, and Riau Residency. Separation line between the two was established by Sir Thomas Stamford Raffles in 1819 that receives Singapore from Abdul Rahman, The Temenggong Sri Maharaja of Johor. He was one of the officers of Johor courts that were located in Bintan Island, Riau (recent day Indonesia). Between Bintan and Singapore, there is Batam Island and on its surroundings, there are maritime societies of Belakang Padang. Abdul Rahman claimed Singapore and some islands north of Riau Islands. Temenggong Abdurrahman then concentrated on building Johor Baru until its peak in 1885 and receives awards from Queen Victoria. The development of the industrial city of Singapore and the region of Riau then separated from Johor Kingdom's control.

\subsubsection{Value development in the Neighbourhood Living of Maritime Society of Belakang Padang, Batam}

Boundary line of Indonesia-Singapore established based on the 1973 agreement, which extended by $1.2 \mathrm{~km}$ by 2009 (see Figure 1). Nipah Island as the outermost island, have the strategic geopolitical value as the national boundary determiner. Reckoning the importance of Nipah Island as the border point in supporting a maritime society of Belakang Padang, which $38 \%$ of its 5,991 people works as fishermen.

On the structural dimension, it is left behind and marginalized because there is no chance for them to access the capitalist economic system with the modern industrialization style. But this is not the only factor that causes them to be marginalized. This marginalization of the Belakang Padang maritime society is that they cannot be accessed into Singapore's development, even though the solution of the problems in Singapore is available at the Belakang Padang society. One of the examples is the environmental condition of Singaporean ports in the west and east of the Outside Port Limits (OPL) region is already packed with ships. 
It is difficult to find adequate space to anchor, even it is very dangerous to anchor during the night, so the possible alternative space is the Belakang Padang region (see Figure 2).

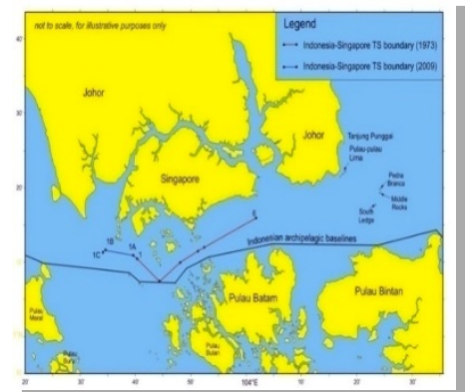

Figure 1. Indonesia-Singapore border map

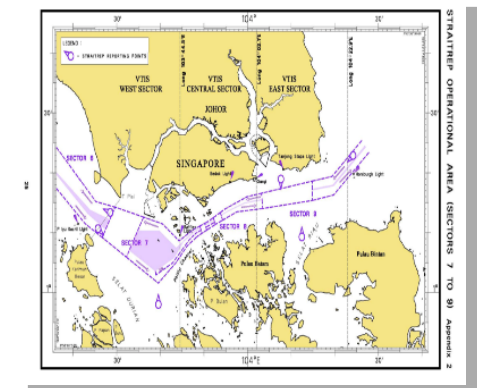

Figure 2. Economic development strategy of Indonesian region.

\subsubsection{Law Norms and Indonesian Government Policy}

Indonesia based on a constitution that aims to achieve prosperity for all of its people, and it indeed includes Belakang Padang maritime society. However, the government has no specific policy for them that directly adjacent to Singapore. The government policies are only to develop Batam Island through the strings of Presidential Policies published from 1971 until 1992.

The development of Batam is backed by strategic geographical condition, which will be expected to receive the overflow of Singapore advancement. For several decades during Soeharto's regime, Batam experience rapid development. But for Belakang Padang society, it has no significant impact. Therefore, development executed by either Indonesian or Singaporean generates almost no impact for them, whereas there are streams of people from out of Batam to seek jobs, mainly from Sumatra, Java, Borneo, Sulawesi, et cetera.

\subsubsection{Potential of Indonesia-Singapore Maritime Collaboration}

Potentials of Belakang Padang that possibly can be developed and collaborated with Singapore are as follows: (1) unique view as a beautiful coastal border that has a potential as maritime tourism spot, (2) quick and easy accessibility from Batam so that Indonesian goods can be gathered through Batam, (3) Small island with low earthquake risk makes this area has a unique housings and its land transport can support the public transport, (4) cultural potentials form the society in the form of traditional games can be developed into an annual festival, and (5) can be a place for cultivating purposes, so that the area can be a farming production options for Singaporeans, and (6) for anchoring, which relates to restocking ship's food and water supplies, management and repairing, weighed and refilling, and health service industries.

\subsection{DISCUSSION}

Genealogy difference between Singaporeans and Belakang Padang people is not considered a fundamental obstacle. Although it roughly has the same area, Singapore is a country and Belakang Padang is merely a district of Indonesia. The relationship between the two cultures in the adjacent neighborhood clearly not a determiner of how close or far a 
society relationship could be. It can be understood that the establishment of Singapore by Raffles was begun with the initial intention to make a country island that able to harness economic potentials of Malacca Strait. One century has passed since the colonials left its footprint that visible with it's dynamic have successfully become a rich country. That success is the part of the colonial's aim. In the realism perspective, Singapore manages to exploits its surroundings' resources so that Belakang Padang society does not hope for anything forevermore. The offer form Soulard about stakeholder collaboration may be the solution, but its possibilities is not exclusively direct towards the Belakang Padang. Footprint of colonial diplomacy problems are faced with a colonial counter-diplomacy as well. Indonesian politics are far more understand the big cities, mainly Jakarta. Therefore, Jakarta is expected to able to understand Belakang Padang society conditions to be involved in maritime economic environmental development in the future.

The low and lazy human resource quality of Belakang Padang cannot be compared with hard-working, Chinese-descent-dominated Singaporeans. Belakang Padang people are mainly religious and surrender to the "fate" that burdened upon them. It is different from the Singaporean mentality to change the useless things by science and technology to become something useful. Making a product with economic values is the superior icon of Singapore.

The principal of life freedom and hard to obey made Belakang Padang community look egoistic and doing something only for their own interest. Even though in a free society they have a norm that must be obeyed by all in a goal. Modern societies are realizing that disciplines are an absolute requirement. "They want to be free, do not want to obey, and doing as they want'. These cultural values shaped the society, so it is hard for them to enter the tight and fast-paced modern life.

Collaboration framework of Koliousis et al. is different from Soulard's that desires prerequirement in the implementation of collaboration reflected in the capacity to be measured and valued from various variable and perspective. This perspective includes the unique and must be considered a thinking paradigm. Because basically maritime society has a dynamic that competitive and collaboration so it can open the possibility of collaboration on every chance. Therefore, not only upgrading the Belakang Padang people's competitiveness but also Singapore itself should be working together. The working method that offered by Koliousis is using an application, a simple method but measurable and dynamic is a possible solution to be considered. Jobs that are already done such as in docks, service, and tourism can be upgraded by this application [8].

\section{Conclusion}

This research visualizes the pattern of society relationship between Singapore and Belakang Padang in the context of strategic culture. The difference of values, symbols, cultures, languages, and leaderships order become differentiator line that impossible to be equalized. To face the future strategic problems, it is possible to involve stakeholders to collaborate in the strategic management framework. As the colonial heritage product, it has developed social order that on one side leave a developed country, but on the other side left behind their surrounding neighborhoods. This collaboration development through strategic management in the future is possible to happen because it is not only profitable and change the Belakang Padang maritime society, but also results in great profit for Singapore's advanced development. Collaboration process for Singaporeans and Belakang Padang people should involve stakeholder in Jakarta, Tanjung Pinang, Batam, and other cities. Culture and tradition 
of Belakang Padang that can be an obstacle can be eradicated by educating and culturing process.

\section{References}

[1] A. D. Basiago, "Economic, social, and environmental sustainability in development theory and urban planning practice," Environmentalist, vol. 19, no. 2, pp. 145-161, 1999.

[2] K. Booth, "The Concept of Strategic Culture Affirmed," in Strategic Power: USA/USSR, C. G. Jacobsen, Ed. London: Palgrave Macmillan, 1990, pp. 121-128.

[3] J. D. Davis, Maritime Security and The Strait of Malacca: A Strategic Analysis. Albany, NY: University of the State of New York, 2006.

[4] J. Soulard, W. Knollenberg, B. B. Boley, R. R. Perdue, and N. G. McGehee, "Social capital and destination strategic planning," Tour. Manag., vol. 69, no. May, pp. 189200, 2018.

[5] H. K. Mohajan, "Qualitative research methodology in social sciences and related subjects," J. Econ. Dev. Environ. People, vol. 7, no. 1, pp. 23-48, 2018.

[6] L. Y. Andaya, Kingdom of Johor, 1641-1728. Kuala Lumpur and New York: Oxford University Press, 1975.

[7] C. A. Trocki, Prince Of Pirates. The Temenggongs and the Development of Johor and Singapore 1784-1885, 2nd ed. Singapore: NUS Press, 2007.

[8] I. G. Koliousis, S. Papadimitriou, E. Riza, P. J. Stavroulakis, and V. Tsioumas, "Strategy, policy, and the formulation of maritime cluster typologies," Mar. Policy, vol. 86, no. June, pp. 31-38, 2017. 